\title{
Podcasting of health sciences lectures: Benefits for students from a non-English speaking background
}

\author{
Karma Pearce and Sheila Scutter \\ University of South Australia
}

\begin{abstract}
Podcasting in higher education is the presentation of study material in digital format that can be downloaded as audio or video files onto a MP3 player or computer. These files can then be accessed anywhere and at any time students choose. The use of podcasting is now widespread amongst undergraduate students, yet their application to the specific needs of students with a non English speaking background (NESB) is largely unknown. The findings of this study are based on a survey of 404 NESB and 708 native English speaking Health Science undergraduate students at the University of South Australia. Ninety percent of NESB students accessed podcasts of undergraduate lectures, with the majority listening to more than 15 podcasts during each semester. The availability of podcasts had limited effect on attendance at lectures. M-learning (mobile learning) was not popular amongst NESB students compared to other students. They preferred to listen to audio recordings of the whole lecture from a computer in conjunction with the PowerPoint presentation. This study suggests the use of podcasts as a revision tool has obvious benefits as perceived by undergraduate NESB students in terms of their learning in face to face classes and when reviewing and revising complex material.
\end{abstract}

\section{Introduction}

Mobile learning (m-learning) is defined as 'the intersection of mobile computing (the application of small, portable, and wireless computing and communication devices) and e-learning (learning facilitated and supported through the use of information and communications technology)' (Quinn 2000; Corbeil \& Valdes-Corbeil, 2007). While the use of MP3 players is relatively new, facilitating learning by providing students with recorded audio material dates back to the 1960s (Forbes \& Hickey, 2008; Van Amelsvoort, 2009). Mobile MP3 devices have for the first time offered a broad group of students a learning technology that is cheap and accessible by most students. Learners who have participated in research projects using MP3 players have largely been quite enthusiastic about the experience of m-learning, with over half reporting that they felt motivated to take part in future learning (Attewell, 2005).

Podcasting is the Internet based distribution of digital, audio or video files in such a way that they can be uploaded onto personal computers or mobile devices such as MP3 players or iPods (Stanley, 2006). This technology offers students light weight devices with long life batteries making for optimum convenience (Cochrane, 2005). Podcasts provide both teachers and students with the opportunity to listen to educational material both inside and beyond the classroom. Traditional text book material can be enhanced with real life learning conversations which deepen learning for students and provide an additional educational opportunity for teachers (Forbes \& 
Hickey, 2008). Podcasts provide students with a learner centred approach with optimal flexibility with regard to the place where they learn or review material; pace - students can choose how fast they learn; peace - students can find a quiet place and time to facilitate learning; and process - students can choose the learning process that best suits their needs (Sharples, Taylor \& Vavoula 2005; Griffin, Mitchell \& Thompson, 2009; Taylor \& Clark, 2010).

Although the use of podcasts has been investigated extensively (Lightbody, McCullagh, Weeks \& Hutchison, 2006; Duncan-Howell \& Lee, 2007; Forbes, 2008; McGarr, 2009; Van Amelsvoort, 2009) their use by the NESB student cohort has not been reported previously. For students whose native language is not English, podcasts are potentially a very useful resource (Read, 2005; O'Bryan \& Helgelheimer, 2007). Although there are currently few published examples of English second language students making use of this technology while studying discipline specific material (O'Bryan \& Helgelheimer, 2007; Nataatmadja \& Dyson, 2008), there are many students for whom English is not their first language currently studying science at university. These students can have difficulty in learning complex concepts as they have the additional hurdle of learning in a second language. Listening has been shown to be an effective tool in the education of all students including NESB students, not just because the spoken word adds lucidity and meaning, but it also is an effective means of motivating students (Durbridge, 1984). Research on the use of multiple modes in learning has largely been based on the 'dual coding' theory of memory and cognition (Paivio, 1969; Paivio, 1978; Paivio, 1986) and the generative theory of multimedia learning (Mayer, 2001). These theories suggest that the verbal and imagery processing systems in the brain work together as alternative coding systems for single pieces of information, so learners who encode things both verbally and visually are believed to learn and retain information more effectively than if it were received through only one mode, regardless of individual cognitive conditions (Paivio, 1969; Austin, 2009).

As well as achieving these instructional goals, podcasts provide students with additional motivation by giving them control over how and when they receive the input (Attewell, 2005). Thorne and Payne suggest that young people, having grown up with the Internet and multimedia, see this technology as a necessary tool for day to day life, including their learning, which also makes possible 'learning and listening on the go' (Thorne \& Payne, 2005; Forbes \& Hickey, 2008). Corbeil and Valdes-Corbeil have also discussed other advantages arising from the use of this technology. One such advantage was enhanced interaction between and among students and instructors when podcasts were combined with other technologies such as smart phones, ultra mobile PCs, tablet PCs, laptops and E-readers. Reduced cultural and communication barriers between faculty and students were also observed. Another is enhanced student-centered learning and supporting the differentiation of student learning needs and personalised learning (Sharma \& Kitchens 2004; Corbeil \& Valdes-Corbeil 2007).

Podcasting is not without disadvantages. Kennedy, Judd, Churchward, Gray \& Krause (2008), Oliver and Goerke (2007), and Dyson, Litchfield, Lawrence, Raban \& Leijdekkers (2009) found that approximately 30\% of students in Australian universities did not own an MP3 player or experienced difficulties when trying to download material (Oliver \& Goerke 2007; Kennedy et al. 2008; Dyson et al. 2009), and thus podcasts could be accessed only via a computer. There is also the risk that outdated and revised instructional material will be uploaded in a new format, rather than created for the new format to engage and motivate the students (Sharma \& Kitchens, 
2004; Corbeil \& Valdes-Corbeil, 2007; Duncan-Howell \& Lee, 2007). Furthermore, as many as $25 \%$ of students choose not to access podcasts because they believe their own note taking during the lecture was sufficient to grasp the key concepts conveyed during lectures (Dyson et al, 2009).

This article aims to investigate the ways in which a large group of students from a selection of health science programs utilise podcasts. The particular focus will be on the ways in which NESB students use podcasts, and whether podcasts could facilitate m-learning by NESB students enrolled in health science face to face courses. This understanding of the way in which NESB students use these resources may be valuable as the University of South Australia moves toward automated vodcasting (video recordings of lectures) in 2011.

\section{Methods}

Podcasts are provided as a supplementary resource for students studying health sciences at our university, with lectures being the predominant teaching method. Lectures were audio-recorded on a portable digital recorder and manually uploaded onto the University of South Australia's learning management system shortly after the lecture as automated recording (as used by von Konsky, Ivins \& Gribble, 2009; Preston, Phillips, Gosper, McNeill, Woo \& Green, 2010) was not available. PowerPoint slides used during lectures were also available for download from the same system.

Survey Monkey software was used to distribute an email based survey to all undergraduate Health Science students. The survey was open between May and July 2009. Health Science students were studying in the areas of Pharmacy, Pharmaceutical Science, Nutrition and Food Sciences, Laboratory Medicine, Physiotherapy, Occupational Therapy, Medical Radiation, Podiatry, Nursing and Midwifery. The survey contained questions about the how and when students used podcasts, and whether they felt they were helpful in their learning. Responses were recorded on a 5point Likert scale with an opportunity for free text responses provided for many questions. Demographic data about work and other commitments, English language status and program and year of their study were also collected. Ethics approval was provided by the University's Human Research Ethics Committee.

Three students indicated that they could not listen to the podcasts because they did not own an iPod or experienced problems downloading the material.

Responses to the survey were downloaded into PASW Statistics version 17 (formerly SPSS Statistics). Analysis focused on comparisons between how NESB and native speaking English students used the podcasts.

\section{Results}

\section{Response rates}

Of the 4480 students enrolled in the division of Health Sciences, just over a quarter of students (1152 students) responded. The number of students responding, the year of their study and program are shown in Table 1 . Thirty five percent of the students responding to the survey were NESB students. This is a slight over-representation, as NESB students comprise approximately $29 \%$ of students in the faculty. 
Overall, students studying Medical Radiation or Nutrition and Food Sciences had a high response rate to the survey; $51 \%$ and $68 \%$ respectively. Lectures were podcast for a longer time in the Medical Radiation program, and this could explain the high response rate for this program. First year students were most likely to respond to the survey. This was followed by second, third and then fourth year students; $40.6 \%$, $32.7 \%, 20.3 \%$ and $6.4 \%$ respectively. Many first year courses form foundation courses for many programs, therefore, typically have a large class size (300-500 students) and are podcast. As Nutrition and Food Sciences, Laboratory Medicine, Pharmaceutical Science, Nursing and Midwifery are all three year programs and many programs have work placements in the fourth year the low response rate of the fourth year students was not unexpected.

Table 1: Programs and year level of students responding to the survey

\begin{tabular}{|c|c|c|c|c|c|c|c|c|c|c|c|c|c|c|c|c|c|c|}
\hline \multirow{3}{*}{$\begin{array}{l}\text { Student } \\
\text { responders } \\
\text { to quest- } \\
\text { ionnaire }\end{array}$} & \multicolumn{12}{|c|}{ What year of the program are you in? } & \multirow{3}{*}{$\begin{array}{c}\text { Total } \\
\mathrm{NE} \\
\mathrm{SB}\end{array}$} & \multirow{3}{*}{\begin{tabular}{|l|} 
Tot. \\
ESB \\
\end{tabular}} & \multirow{3}{*}{$\begin{array}{c}\text { Stud- } \\
\text { ents in } \\
\text { prog. }\end{array}$} & \multirow{3}{*}{$\begin{array}{c}\text { NESB } \\
\% \text { resp- } \\
\text { onders }\end{array}$} & \multirow{3}{*}{$\begin{array}{l}\text { ESB \% } \\
\text { resp- } \\
\text { onders }\end{array}$} & \multirow{3}{*}{$\begin{array}{c}\text { Total \% } \\
\text { resp- } \\
\text { onders }\end{array}$} \\
\hline & \multicolumn{3}{|c|}{ First Year } & \multicolumn{3}{|c|}{ Second Year } & \multicolumn{3}{|c|}{ Third Year } & \multicolumn{3}{|c|}{ Fourth Year } & & & & & & \\
\hline & $\begin{array}{l}\mathrm{NE} \\
\mathrm{SB}\end{array}$ & $\begin{array}{c}\text { ES } \\
B\end{array}$ & $\mathrm{~T}$ & $\begin{array}{l}\text { NE } \\
\text { SB }\end{array}$ & \begin{tabular}{|c|} 
ES \\
$B$
\end{tabular} & $\mathrm{~T}$ & $\begin{array}{l}\mathrm{NE} \\
\mathrm{SB}\end{array}$ & $\begin{array}{c}\text { ES } \\
B\end{array}$ & $\mathrm{~T}$ & $\begin{array}{l}\text { NE } \\
\text { SB }\end{array}$ & $\begin{array}{c}\text { ES } \\
\text { B }\end{array}$ & $\mathrm{T}$ & & & & & & \\
\hline Pharm. & 36 & 26 & 62 & 34 & 22 & 56 & 64 & 37 & 101 & 37 & 22 & 59 & 171 & 107 & 670 & $26 \%$ & $16 \%$ & $41 \%$ \\
\hline Pharm. Sci. & 8 & 6 & 14 & 9 & 9 & 18 & 2 & 0 & 2 & 0 & 0 & 0 & 19 & 15 & 76 & $25 \%$ & $20 \%$ & $45 \%$ \\
\hline Nut. F. S. & 4 & 18 & 22 & 1 & 15 & 16 & 4 & 6 & 10 & 0 & 0 & 0 & 9 & 39 & 71 & $13 \%$ & $55 \%$ & $68 \%$ \\
\hline Lab. Med. & 7 & 9 & 16 & 1 & 11 & 12 & 3 & 3 & 6 & 2 & 4 & 6 & 13 & 27 & 134 & $10 \%$ & $20 \%$ & $30 \%$ \\
\hline Nursing & 42 & 105 & 147 & 51 & 88 & 139 & 15 & 42 & 57 & 0 & 0 & 0 & 108 & 235 & 1868 & $6 \%$ & $13 \%$ & $18 \%$ \\
\hline Midwif. & 2 & 9 & 11 & 1 & 10 & 11 & 0 & 0 & 0 & 0 & 0 & 0 & 3 & 19 & 174 & $2 \%$ & $11 \%$ & $13 \%$ \\
\hline Occ. Th. & 4 & 23 & 27 & 0 & 12 & 12 & 0 & 7 & 7 & 1 & 7 & 8 & 5 & 49 & 272 & $2 \%$ & $18 \%$ & $20 \%$ \\
\hline Podiatry & 6 & 8 & 14 & 0 & 0 & 0 & 1 & 0 & 1 & 0 & 1 & 1 & 7 & 9 & 86 & $8 \%$ & $10 \%$ & $19 \%$ \\
\hline Physio. & 18 & 25 & 43 & 7 & 18 & 25 & 1 & 15 & 16 & 1 & 18 & 19 & 27 & 76 & 403 & $7 \%$ & $19 \%$ & $26 \%$ \\
\hline Med. Rad. & 22 & 32 & 54 & 7 & 28 & 35 & 8 & 20 & 28 & 0 & 0 & 0 & 37 & 80 & 230 & $16 \%$ & $35 \%$ & $51 \%$ \\
\hline Health Sci. & 2 & 23 & 25 & 0 & 10 & 10 & 1 & 0 & 1 & 0 & 1 & 1 & 3 & 34 & 79 & $4 \%$ & $43 \%$ & $47 \%$ \\
\hline Hum. Mov. & 2 & 55 & 57 & 0 & 1 & 1 & 0 & 1 & 1 & 0 & 1 & 1 & 2 & 58 & 417 & $0 \%$ & $14 \%$ & $14 \%$ \\
\hline Total & 153 & 339 & 492 & 111 & 224 & 335 & 99 & 131 & 230 & 41 & 54 & 95 & 404 & 748 & 4480 & $9 \%$ & $17 \%$ & $26 \%$ \\
\hline
\end{tabular}

Key for column 1: Pharm. = Pharmacy; Pharm. Sci. = Pharmaceutical Science; Nut. F. S. =

Nutrition and Food Sciences; Lab. Med. = Laboratory Medicine; Midwif. Midwifery; Occ. Th. = Occupational Therapy; Physio = Physiotherapy; Med. Rad. = Medical Radiation; Hum. Mov. = Human movement. In columns 4, 7, 10 and 13, $\mathrm{T}=$ Total.

\section{Use of podcasts}

Podcasts were provided for at least one course for $92 \%$ of survey respondents. Of these students, $87 \%$ had listened to at least one podcast. Nearly half of the students who had accessed podcasts had listened to at least 10 podcasts, indicating that students were spending a considerable amount of time listening to podcasts. Figure 1 shows the use of podcasts by students for whom English was a second language compared to native English speakers. As can be seen, both groups of students listened to a considerable number of podcasts. Analysis of variance indicated that NESB students listened to significantly more podcasts than non-NESB students $(\mathrm{p}<0.01)$. The use of podcasting by NESB students over the first three years of their studies increased from $31 \%$ to $33 \%$ to $43 \%$ respectively. These students found podcasting more beneficial for their learning, possibly because 'sound slows our interpretation of words and ideas as the speed of listening is slower than reading' (Brabazon, 2006).

Overall, the frequency at which podcasts were accessed increased as students progressed through their programs; the majority of first year students listened to less than 10 podcasts during each semester, whereas almost a third of the second year and almost half of third year students listened to more than 15 podcasts. As shown in Figure 2, the percentage of NESB students listening to more than 15 podcasts increased 
substantially in later years of study. Students in later years of the program listened to more podcasts compared to students in their first year $(\mathrm{p}>0.05)$.

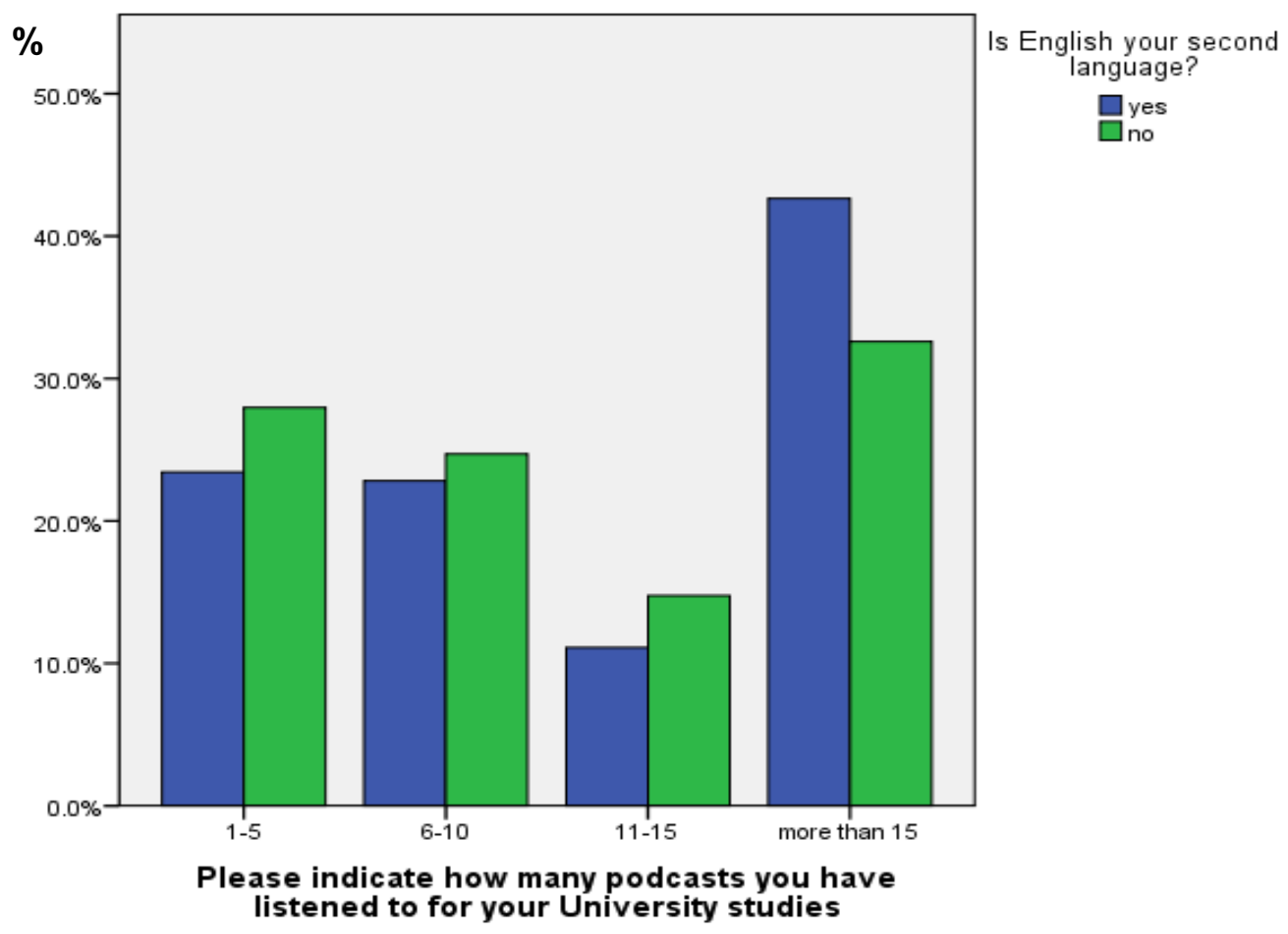

Figure 1: The number of podcasts listened to by NESB and ESB students

Podcast use varied according to the program in which students were enrolled. Students in the Pharmacy program listened to significantly more podcasts than other students, whereas Laboratory Medicine and Nutrition and Food Sciences listened to significantly less $($ Chi-square $=23.4, p<0.023)$. Further examination of the data revealed no significant differences between the listening habits of NESB and ESB students and their use of MP3 players and computers ( $p>0.05$ for both).

Table 2 describes the times when students listened to their podcasts. Overall, students mainly listened to podcasts when they were studying $(48 \%)$, rather than when they were exercising $(12 \%)$ or in paid work $(7 \%)$. Other times that students listened to podcasts were when they were traveling $(27 \%)$, while they were lying in bed or sleeping $(20 \%)$ or doing other activities or relaxing around the house $(16 \%)$. Only $21 \%$ of the 155 respondents listened to podcasts because they couldn't attend lectures. Of interest is the significant decrease in the number of students using podcasts when they could not attend lectures as they progressed from first to third year of their studies $(p<0.01)$. Three students indicated that they could not listen to the podcasts because they did not own an iPod or experienced problems downloading the material. Although most students used the podcasts to revise, the number of students lying on their bed or sleeping while listening to their podcasts increased as they progressed through their studies. 


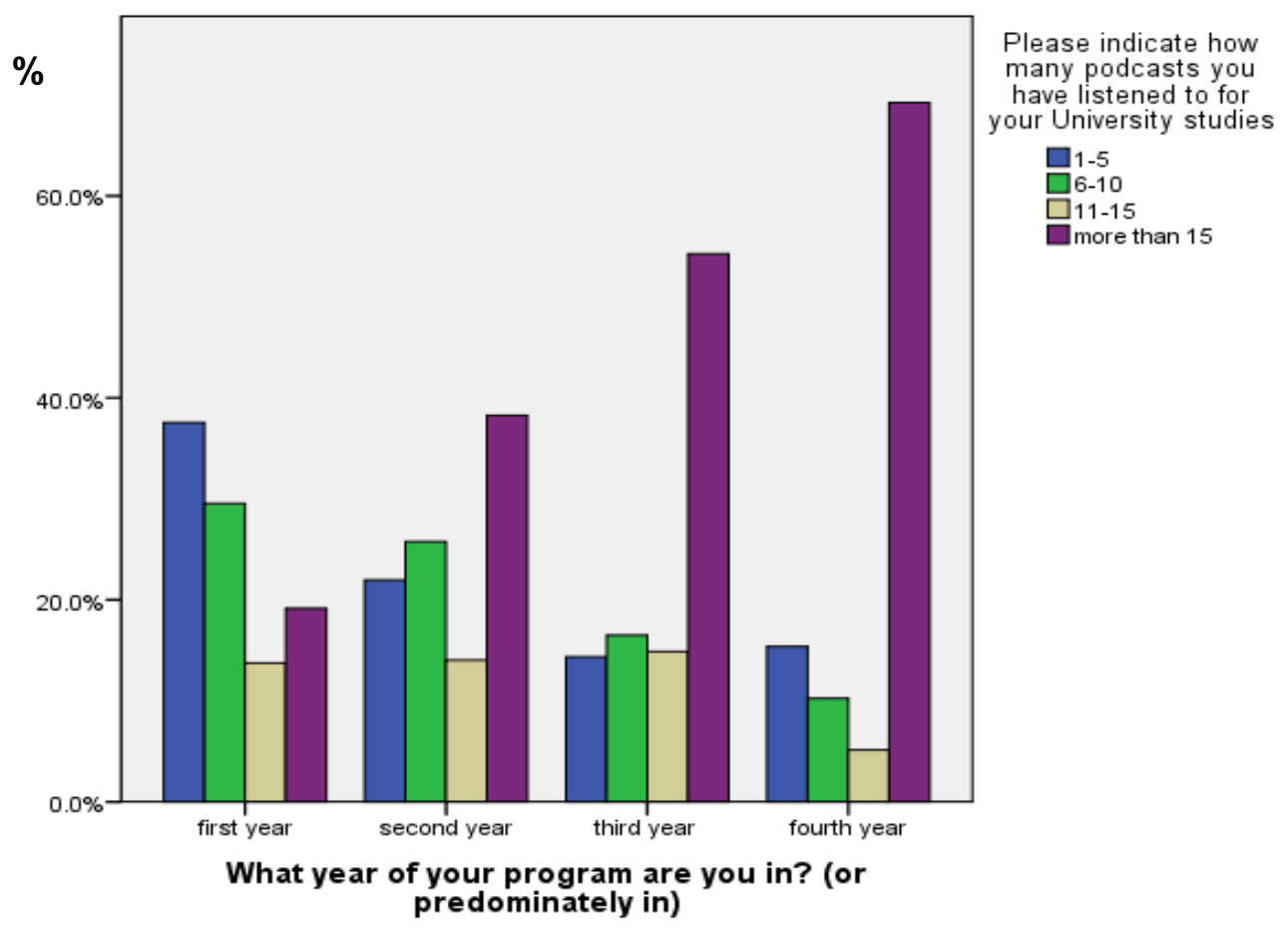

Figure 2: Podcast use by program year

Table 2: The ways in which students listened to their podcasts throughout their study Note: Several students listed multiple ways of listening to their podcasts.

\begin{tabular}{|c|c|c|c|c|c|c|c|c|c|}
\hline \multirow{3}{*}{\begin{tabular}{|r|} 
Description \\
Preparing for exams
\end{tabular}} & \multirow{2}{*}{\multicolumn{2}{|c|}{$\begin{array}{c}\text { First year } \\
\mathrm{n}=71\end{array}$}} & \multirow{2}{*}{\multicolumn{2}{|c|}{$\begin{array}{c}\text { Second year } \\
\mathrm{n}=55\end{array}$}} & \multirow{2}{*}{\multicolumn{2}{|c|}{$\begin{array}{c}\text { Third year } \\
\mathrm{n}=24\end{array}$}} & \multirow{2}{*}{\multicolumn{2}{|c|}{$\begin{array}{c}\text { Fourth year } \\
\mathrm{n}=5\end{array}$}} & \multirow{3}{*}{$\begin{array}{c}\text { Total } \\
\mathrm{N}=155 \\
31 \%\end{array}$} \\
\hline & & & & & & & & & \\
\hline & 21 & $27 \%$ & 14 & $21 \%$ & 9 & $31 \%$ & 4 & $50 \%$ & \\
\hline Couldn't attend lecture & 23 & $30 \%$ & 5 & $7 \%$ & 3 & $10 \%$ & 2 & $25 \%$ & $21 \%$ \\
\hline Traveling & 7 & $9 \%$ & 13 & $19 \%$ & 5 & $17 \%$ & 2 & $25 \%$ & $17 \%$ \\
\hline Relaxing on bed / sleeping & 7 & $9 \%$ & 7 & $10 \%$ & 6 & $21 \%$ & 0 & $0 \%$ & $13 \%$ \\
\hline While exercising & 8 & $10 \%$ & 11 & $16 \%$ & 3 & $10 \%$ & 0 & $0 \%$ & $14 \%$ \\
\hline $\begin{array}{l}\text { While relaxing (hobbies / } \\
\text { computer games / family) }\end{array}$ & 5 & $6 \%$ & 8 & $12 \%$ & 3 & $10 \%$ & 0 & $0 \%$ & $10 \%$ \\
\hline While at work & 2 & $3 \%$ & 5 & $7 \%$ & 0 & $0 \%$ & 0 & $0 \%$ & $5 \%$ \\
\hline During breaks at uni & 2 & $3 \%$ & 4 & $6 \%$ & 0 & $0 \%$ & 0 & $0 \%$ & $4 \%$ \\
\hline
\end{tabular}

As shown below in Table 3, NESB students mostly listened to podcasts while revising, relaxing on their beds/ sleeping or relaxing at home and rarely listened to podcasts while traveling. In contrast, a higher number of ESB students listened to podcasts while they were traveling ( $5 \%$ cf. $18 \%$ respectively; $\mathrm{p}<0.01$ ).

Students were asked about the ways in which they used podcasts to assist in their learning. Approximately $50 \%$ of both NESB and ESB students listened to the whole podcast, whereas 7 to $12 \%$ reported 'flicking through' the lecture. Furthermore, 20-23\% tried to review a specific portion of the lecture, suggesting that these both NESB and ESB students were seeking assistance to 'fill in the gaps' or consolidate their learning in key areas. 
Table 3: When do students listen to podcasts?

\begin{tabular}{|l|c|c|c|c|c|}
\hline \multirow{2}{*}{ Description } & \multicolumn{2}{|c|}{ NESB } & \multicolumn{2}{c|}{ ESB } & Total \\
\cline { 2 - 6 } & $\mathrm{n}=38$ & $\%$ & $\mathrm{n}=116$ & $\%$ & $\mathrm{~N}=154$ \\
\hline Revision & 13 & $30 \%$ & 34 & $25 \%$ & $48 \%$ \\
\hline Couldn't attend lecture & 7 & $16 \%$ & 26 & $19 \%$ & $33 \%$ \\
\hline Travelling & 2 & $5 \%$ & 25 & $18 \%$ & $27 \%$ \\
\hline Relaxing on bed / sleeping & 7 & $16 \%$ & 13 & $9 \%$ & $20 \%$ \\
\hline Exercise & 4 & $9 \%$ & 18 & $13 \%$ & $22 \%$ \\
\hline Relaxing at home (hobbies, computer games, family) & 7 & $16 \%$ & 9 & $7 \%$ & $16 \%$ \\
\hline While at work & 1 & $2 \%$ & 6 & $4 \%$ & $7 \%$ \\
\hline Breaks during week days & 3 & $7 \%$ & 3 & $2 \%$ & $6 \%$ \\
\hline
\end{tabular}

Students were asked, 'If I know that the lecture will be podcast does it impact on what I do in lectures?' Just over half of students reported not changing their class or study behaviour if they knew a lecture was podcast. However, almost half of the students reported taking fewer notes, a third reported asking fewer questions, and only $11 \%$ reported asking more questions during class. These figures increased when the data was examined for NESB students; 59\% reported taking less notes, $17 \%$ asked less questions in class and $41 \%$ asked more questions. Comments from all students, including NESB students, indicated that if a lecture was podcast they could concentrate on what was being taught and discussed in the lecture rather than focus on note taking. This allowed them to understand the context of what was said in lecture and take notes or clarify difficult concepts at a later time. Frustration, however, was expressed when occasionally the podcast of the same topic given by another lecturer was the only copy made available or in the event that the technology failed, no podcast was provided.

NESB students remarked on the value of being able to 'pause' the podcast so that they could look up words or terms as needed, listen to the material at their own pace and assimilate the material presented before progressing to the next part of the lecture.

Overall, students did not show a strong preference to studying with the PowerPoint slides which were uploaded along with the podcasts; $48 \%$ and $52 \%$ of students studied with and without PowerPoint respectively. In contrast, $80 \%$ of NESB students stated that they 'often' or 'occasionally' studied with PowerPoint suggesting that viewing the PowerPoint presentation of the lecture in conjunction with the corresponding podcasts helped to review or reinforce content covered in lecture (NESB cf. ESB; $f=20.3$, $\mathrm{p}<0.000)$.

Perhaps alarmingly, $66 \%$ of respondents never studied straight after the lecture while $64 \%$ never studied within a few days of the lecture. Thirty nine percent and $46 \%$ of students reported using the podcast to 'often' and 'occasionally' study for exams with the majority of respondents (96\%) declaring that podcasts were 'very useful' to clarify information and $96 \%$ of respondents also indicated that they listened to the podcast to memorise facts. At least half the NESB students studied 'straight after the lecture' or 'within a few days of the lecture' and with the PowerPoint presentation. Eighty-six percent of NESB students used the podcasts to study for exams, $79 \%$ found them 'very useful' to clarify key points, and $90 \%$ used them to memorise key facts. During these study sessions $63 \%$ of NESB students listened to the 'whole' podcast while $27 \%$ 'tried to find the part that [they] needed to review'. 
The majority of students thought all classes should be podcast ( $97 \%$ for NESB, $97 \%$ of ESB). Using an open ended question, students were asked to describe any possible disadvantages to podcasts. One third of both NESB and ESB students listed disadvantages to podcasts. The most common disadvantages cited were 'time to listen to the podcasts', 'sound quality' and 'diagrams on the board' or 'something done physically can't be reproduced on a podcast'. Others listed podcasts as 'boring', 'they make you lazy' and they 'give you a false sense of security'.

Those students who stated that they did not use the podcasts were asked about the different reasons that led to their decision (Fietze, 2009). Only 12\% (133) of students indicated that they did not listen to podcasts with the majority of these students indicating that they found other methods of study more effective $(62 \%)$ and they did not have time to listen to the podcasts $(51 \%)$. Similar patterns were observed with NESB students; $10 \%$ of these students indicated that they did not listen to podcasts with the key reason listed as lack of time.

To investigate one of the reasons why students may not have time to listen to podcasts, students were asked how many hours per week they worked. Two thirds of the students worked less than 10 hours per week, while $11 \%$ worked more than 20 hours per week. Again similar patterns were seen with NESB students with $56 \%$ working less than 5 hrs per week and 6\% working more than 20 hours per week.

\section{Discussion}

This study has provided valuable feedback on the usage of podcasting by NESB Health Science students. Frequency of podcast use increased as all students progressed through their studies. A much stronger trend was observed for NESB students. This suggests that all students, but in particular NESB students, found a benefit in supplementing their learning with this form of technology (Copley, 2007), possibly because 'sound slows our interpretation of words and ideas as the speed of listening is slower than reading' (Brabazon, 2006).

The use of m-learning tools themselves does not guarantee its potential being realised. NESB and non-NESB students both preferred to listen to their podcasts on computers rather than on MP3 players or iPods. Anecdotally, this is surprising, as students regularly arrive in class, and walk around campus listening to MP3 players. However, these results are consistent with those of other researchers such as Copley (2007), Forbes and Hickey (2008) and Lane (2006) who all reported students showing a strong preference for listening to podcasts via computers rather than mobile devices. This study found this to be an even stronger preference among NESB students, who preferred to listen to podcasts via a computer at home.

NESB students did not favour the use of iPods or m-learning, but preferred to listen to the whole podcast from a computer in conjunction with the PowerPoint presentation of the lecture. A possible explanation for this may be the lack of suitability for NESB students of iPods coupled with complex, content rich courses (Lightbody et al., 2006) delivered by the Division of Health Sciences. Bell et al. (2007) expressed concerns with students listening to podcasts while performing other activities, e.g. riding a bike or exercising, as they are likely to have only part of their attention devoted to hearing the podcast and have limited opportunity to take notes (Bell et al. 2007). It is possible that NESB students felt the need to devote their full attention to podcasts while actively 
listening and taking notes, thus avoided listening to the podcasts while engaged in other activities. However, Laing and Wootton (2007) point out that as the 'learner will probably be listening to your podcast whilst carrying out another task such as walking, sitting on a bus or exercising... podcasts should avoid dense complex material which is better covered in a lecture' (Laing \& Wootton 2007). Another explanation may be that the audio copy of a lecture designed for a face to face class does not lend itself to mlearning and reinforces the need to use exemplary pedagogy designed to facilitate learning any place, any time (Copley, 2007). This medium must also excite, and motivate students to learn without the 3 dimensional stimuli of a lecture theatre (Copley, 2007). Furthermore, NESB students may value collaborative interaction in which students negotiate meanings and obtain comprehensible language input which is lacking in a podcast (Kasper, 2000). The usefulness of m-learning is based on the premise that students can deal with the cognitive load of multitasking, i.e. listening to the audio podcasts while performing other activities (McGarr, 2009). One explanation for our research results may be that the added language difficulties of NESB students means that these students experience cognitive overload with m-learning and opt for a designated study time and place.

NESB students listened to more than 15 podcasts each semester compared to nonNESB students. NESB students studying Pharmacy in particular were high users of the technology across all 4 years of the program. Although most students, including NESB students, reported using the podcasts to revise, the number of students lying on their bed or sleeping while listening to their podcasts increased as they progressed through their studies suggested students used podcasts for both 'active' and 'passive' listening. Learning which occurs from just listening to podcasts is described by Dyson et al. (2009) as passive learning, which results only in surface learning. Students' views were partially consistent with this in that they described using podcasts when they needed to 'get knowledge into their heads' (Dyson et al. 2009). The opportunity to re-listen to a lecture and to take additional notes also appears to facilitate a transition mode of delivery in learning (Forbes, 2008; Scutter, Stupans, Sawyer \& King, 2010).

Two-thirds of the overall respondents reported never studying straight after the lecture or within a few days of the lecture. Although students need to make choices about their learning, this practice could significantly impact on the preparation and outcomes of tutorial or practical classes held within a few days of the lecture and lead to students rapidly becoming behind with their studies (Bell et al. 2007). In contrast to the whole student cohort, at least half the NESB students studied 'straight after the lecture' or 'within a few days of the lecture' and used the PowerPoint presentation. Most NESB students used the podcasts to study for exams, found them very useful' to clarify key points, and used them to memorise key facts. However, whether students are able to use these 'facts' to build and construct information remains unknown in this context. During these study sessions, over half the students listened to the 'whole' podcast, while only a quarter tried to find 'the part that they needed to review'.

Overall, students did not show a strong preference to studying with PowerPoint with about half of the group reporting that they did or did not watch the presentation while listening. In contrast, four out of five NESB students stated that they 'often' or 'occasionally' studied with PowerPoint suggesting that viewing the PowerPoint presentation in conjunction with podcasts helped them to review or reinforce content covered in lectures. 
Our findings show that having podcast lectures available to students does not lead to large declines in lecture attendance. NESB and non-NESB students intentionally missed fewer face to face classes as they progressed through their studies, notwithstanding the availability of audio reproductions of the lectures. This is in contrast to concerns raised by some (Lightbody et al., 2006; Malan, 2007; Grabe \& Christopherson, 2008; von Konsky et al., 2009), but not all (Bongey et al., 2006; Shannon, 2006; Copley, 2007; Forbes \& Hickey, 2008; Fietze, 2009). There is a number of possible reasons to explain this. At a fundamental level, a lecture is a transfer of information, but it should also inspire, enthuse and excite students. The lecturer's research, knowledge and 'real world' experience should provide clarity and insight into complex concepts which should be linked to real life examples. Social interaction, discussion and debate should also flow within such a setting. Hence, the lecture should be a multi faceted experience which cannot be provided by a podcast alone (Brabazon, 2006).

Not surprisingly, the majority of students thought all classes should be podcast. Again, this view was stronger among NESB students, suggesting that these students valued the provision of podcasts as part of a 'blended approach' to learning (Attewell, 2005; Duncan-Howell \& Lee, 2007). Of concern is the finding that nearly every student declaring that podcasts were 'very useful' to clarify information and to memorise facts. In a study conducted by Evans (2008), 200 students believed that podcasts are more effective revision tools than their textbooks and they were more efficient than their own notes in helping them to learn.

One third of students in both groups listed disadvantages to podcasts. The most common disadvantages cited were time, sound quality and that 'diagrams on the board' or 'something done physically cannot be reproduced on a podcast'. This is consistent with the current literature (Attewell, 2005; McGarr, 2009). Others listed podcasts as 'boring'. The fact that some students though the podcasts were 'boring' highlights the need to use pedagogically appropriate delivery for podcasting (Attewell, 2005; Campbell, 2005; Brabazon, 2006). Attewell (2005) reported that podcasts were also used to remove some of the formality which non-traditional learners found unattractive, however this was not an issue in this study.

To determine the effectiveness of audio lectures on higher education, McKinney et al. (2009) conducted a study in which undergraduate psychology students participated in an experiment. Approximately half the students attended a 25 minute lecture while the remaining students were provided with a podcast of the lecture. All students were provided with copies of the slides to aid note taking. A week later, students were examined on the contents of the lecture. The results indicated that students who listened to the podcast scored significantly higher than students who attended the face to face class (McKinney et al. 2009). The next step in this research is to evaluate possible improvements in learning outcomes as a result of podcasts for NESB students.

Students in later years of the program listened to more podcasts compared to students in their first year. Students' podcast use varied according to the program in which they were enrolled. Students in the Pharmacy program listened to significantly more podcasts than other students, whereas Laboratory Medicine and Nutrition and Food Sciences listened to significantly fewer (Chi-square $=23.4, p<0.023$ ). Several courses in the Nutrition and Food Sciences program involve the sensory analysis of foods and are deliberately not podcasts. Such content cannot be learnt 'aurally'; possessing the skills 
to evaluate the tastes, textures and the aroma of food can only be taught successfully in a face to face setting when all the senses were involved in the learning process. The heavy use of podcasts by students studying Pharmacy is of interest. NESB students used podcasts significantly more than non-NESB students in this program and, in fact, were the highest "consumers" of podcasts in the whole Division. Pharmacy is a highcontent, demanding program with an emphasis on communication skills. There is a high proportion of NESB students in this program. This is in contrast to what was observed overall, and may be due to the higher relative percentage of NESB students responding from this program and the increased pressure on students in this particular course to achieve good grades before their placement year. Students were asked about the ways in which they listened to podcasts. Despite the ability to load the podcast onto a portable device, only a third of students ordinarily downloaded their podcasts to iPods or MP3 players with the remaining two thirds using their computers. Further examination of the data revealed no significant differences between the listening habits of NESB and ESB students and their use of MP3 players and computers.

\section{Conclusion}

In conclusion, nearly all NESB students utilised the supplementary audio copy of their lectures, with the majority listening to more than 15 podcasts during each semester. As evidenced by this survey, podcasting a lecture had limited effect on NESB student attendance at face to face lectures, while students reported podcasts as 'very useful' in supplementing their learning by assisting in engagement with key concepts rather than note taking during face to face classes. Podcasting also provided auxiliary, self paced methods to 'digest' difficult concepts and facilitate better revision and preparation for exams, although students showed a preference for dedicated revision sessions combining audio with PowerPoint.

\section{References}

Attewell, J. (2005). From research and development to mobile learning: Tools for education and training providers and their learners. Proceedings 4th World Conference on mLearning, 2005. [verified 23 Dec 2010] http: / / www.mlearn.org.za/CD/papers/Attewell.pdf

Austin, K. A. (2009). Multimedia learning: Cognitive individual differences and display design techniques predict transfer learning with multimedia learning modules. Computers $\mathcal{E}$ Education, 53(4), 1339-1354.

Bell, T., Cockburn, A., Wingkvist, A. \& Green, A. (2007). Podcasts as a supplement in tertiary education: An experiment with two computer science courses. Proceedings MoLTA 2007. [verified 23 Dec 2010] http:/ / ir.canterbury.ac.nz/ bitstream/10092/482/1/12602889_podcast.pdf

Bongey, S., Cizadlo, G. \& Kalnbach, L. (2006). Explorations in course-casting: Podcasts in higher education. Campus-Wide Information Systems, 23(5), 350-367.

Brabazon, T. (2006). Socrates in earpods? The Ipodification of education. Fast Capitalism, 2(1). [verified 23 Dec 2010] http: / / www.uta.edu/huma/agger/fastcapitalism/2_1/brabazon.htm

Campbell, G. (2005). There is something in the air: Podcasting in education. EDUCAUSE Review, 40(6), 32-47. http:/ / www.educause.edu/EDUCAUSE+Review/EDUCAUSE ReviewMagazineVolume40/TheresSomethingintheAirPodcast/158014 
Cochrane, T. (2005). Mobilising learning: A primer for utilising wireless palm devices to facilitate a collaborative learning environment. In Balance, fidelity, mobility: Maintaining the momentum? Proceedings ASCILITE Brisbane 2005.

http: / / www.ascilite.org.au/conferences/brisbane05/blogs/proceedings/16_Cochrane.pdf

Copley, J. (2007). Audio and video podcasts of lectures for campus-based students: Production and evaluation of student use. Innovations in Education and Teaching International, 44(4), 387399.

Corbeil, J. \& Valdes-Corbeil, M. E. (2007). Are you ready for mobile learning? EDUCAUSE Quarterly, 30(2). http:/ / www.educause.edu/EDUCAUSE+Quarterly/EDUCAUSEQuarterly MagazineVolum/AreYouReadyforMobileLearning/157455

Duncan-Howell, J. \& Lee, K. (2007). M-learning: Finding a place for mobile technologies within tertiary educational settings. In ICT: Providing choices for learners and learning. Proceedings ascilite Singapore 2007. http:/ / www.ascilite.org.au/ conferences/ singapore07/ procs/duncanhowell.pdf

Durbridge, N. (1984). Media in course design. In A. Bates (Ed), The role of technology in distance education. London: Croom Helm.

Dyson, L. E., Litchfield, A., Lawrence, E., Raban, R. \& Leijdekkers, P. (2009). Advancing the mlearning research agenda for active, experiential learning: Four case studies. Australasian Journal of Educational Technology, 25(2), 250-267.

http:/ / www.ascilite.org.au/ajet/ajet25/dyson.html

Dyson, L.E., Litchfield, A., Raban, R. \& Tyler, J. (2009). Reflections on interactive classroom mLearning and the experiential transactions between students and lecturer. In Same places, different spaces. Proceedings ascilite Auckland 2009.

http: / / www.ascilite.org.au/conferences/auckland09/procs/dyson.pdf

Evans, C. (2008). The effectiveness of m-learning in the form of podcast revision lectures in higher education. Computers $\mathcal{E}$ Education, 50(2), 491-498.

Fietze, S. (2009). Podcast in higher education: Students usage behaviour. In Same places, different spaces. Proceedings ascilite Auckland 2009.

http: / / www.ascilite.org.au/conferences/ auckland09/procs/fietze.pdf

Forbes, M. O. \& Hickey, M. T. (2008). Podcasting: Implementation and evaluation in an undergraduate nursing program. Nurse Educator, 33(5), 224-227.

Grabe, M. \& Christopherson, K. (2008). Optional student use of online lecture resources: Resource preferences, performance and lecture attendance. Journal of Computer Assisted Learning, 24(1), 1-10.

Griffin, D. K., Mitchell, D. \& Thompson, S. J. (2009). Podcasting by synchronising PowerPoint and voice: What are the pedagogical benefits? Computers $\mathcal{E}$ Education, 53(2), 532-539.

Kasper, L. (2000). New technologies, new literacies: Focus discipline research and ESL learning communities. Language Learning and Technology, 4(2), 105-128.

http: / /lt.msu.edu/vol4num2/kasper/ default.html

Kennedy, G. E., Judd, T. S., Churchward, A., Gray, K. \& Krause, K.-L. (2008). First year students' experiences with technology: Are they really digital natives? Australasian Journal of Educational Technology, 24(1), 108-122. http:/ / www.ascilite.org.au/ajet/ajet24/ kennedy.html 
Laing, C. \& Wootton, A. (2007). Using podcasts in higher education. He@lth Information on the Internet, 60(1), 7-9. http:/ / hii.rsmjournals.com/ cgi/reprint/60/1/7

Lane, C. (2006). Podcasting at the UW: An evaluation of current use. The Office of Learning Technologies, University of Washington. http:/ / www.washington.edu/lst/ research _development/papers/2006/podcasting_report.pdf

Lightbody, L., McCullagh, P., Weeks, C. \& Hutchison, M. (2006). The supporting role of emerging multimedia technologies in higher education. In The Higher Education Academy: Information and Computer Sciences 7th Annual Conference, Dublin, 29-31 August. pp.49-54. [verified 23 Dec 2010] http: / / www.ics.heacademy.ac.uk/Events/HEADublin2006_V2/ papers / Gaye\%20Lightbody\%209.pdf

Malan, D. J. (2007). Podcasting computer science E-1. In SIGCSE 2007: Proceedings of the ThirtyEighth SIGCSE Technical Symposium on Computer Science Education, March 7-10, 2007, Covington, Kentucky. [verified 23 Dec 2010] http: / / dash.harvard.edu/handle/1/2829931

Mayer, R. E. (Ed). (2001). Multimedia learning. Cambridge, UK: Cambridge University Press.

McGarr, O. (2009). A review of podcasting in higher education: Its influence on the traditional lecture. Australasian Journal of Educational Technology, 25(3), 309-321. http:/ / www.ascilite.org.au/ajet/ajet25/mcgarr.html

McKinney, D., Dyck, J. L. \& Luber, E. S. (2009). iTunes University and the classroom: Can podcasts replace professors? Computers $\mathcal{E}$ Education, 52(3), 617-623.

Nataatmadja, I. \& Dyson, L. E. (2008). The role of podcasts in students' learning. International Journal of Interactive Mobile Technologies, 2(3), 17-21.

O'Bryan, A. \& V. Helgelheimer (2007). Integrating CALL into the classroom: The role of podcasting in an ESL listening strategies course. ReCALL Journal, 19(2), 162-180.

Oliver, B. \& Goerke, V. (2007). Australian undergraduates' use and ownership of emerging technologies: Implications and opportunities for creating engaging learning experiences for the Net Generation. Australasian Journal of Educational Technology, 23(2), 171-186. http:/ / www.ascilite.org.au/ajet/ajet23/oliver.html

Paivio, A. (1969). Mental imagery in associative learning and memory. Psychological Review, 76(12), 241-263. [verified 23 Dec 2010] http:/ / www.garfield.library.upenn.edu/classics1979 / A1979HZ25300001.pdf

Paivio, A. (1978). Imagery, language, and semantic memory. International Journal of Psycholinguistics, 5, 31-47.

Paivio, A. (Ed). (1986). Mental representations: A dual-coding approach. New York: Oxford University Press.

Preston, G., Phillips, R., Gosper, M., McNeill, M., Woo, K. \& Green, D. (2010). Web-based lecture technologies: Highlighting the changing nature of teaching and learning. Australasian Journal of Educational Technology, 26(6), 717-728.

http: / / www.ascilite.org.au/ajet/ajet26/preston.html

Quinn, C. (2000). mLearning: Mobile, wireless, in-your-pocket learning. LiNE Zine, Fall 2000. [verified 23 Dec 2010] http: / / www.linezine.com/2.1/ features/cqmmwiyp.htm

Read, B. (2005). Lectures on the go. The Chronicle of Higher Education, 28 October 2005. 
Scutter, S., Stupans, I., Sawyer, T. \& King, S. (2010). How do students use podcasts to support learning? Australasian Journal of Educational Technology, 26(2), 180-191. http:/ / www.ascilite.org.au/ajet/ajet26/scutter.html

Shannon, S. (2006). Why don't students attend lectures and what can be done about it through using iPod nanos? In Who's learning? Whose technology? Proceedings ascilite Sydney 2006. http: / / www.ascilite.org.au/conferences/sydney06/proceeding/pdf_papers/p28.pdf

Sharma, S. K. \& Kitchens, F. L. (2004). Web services architecture for m-learning. Electronic Journal of e-Learning, 2(1), 203-216

Sharples, M., Taylor, J. \& Vavoula, G. (2005). Towards a theory of mobile learning. Proceedings of MLearn 2005 Conference. [verified 23 Dec 2010]

http: / / www.mlearn.org.za/CD / papers /Sharples-\%20Theory\%20of\%20Mobile.pdf

Stanley, G. (2006). Podcasting: Audio on the Internet comes of age. TESL-EJ, 9(4). http: / / www.tesl-ej.org/wordpress/issues/volume9/ ej36/ ej36int/

Taylor, L. \& Clark, S. (2010). Educational design of short, audio-only podcasts: The teacher and student experience. Australasian Journal of Educational Technology, 26(3), 386-399. http: / / www.ascilite.org.au/ajet/ajet26/taylor.html

Thorne, S. \& J. Payne (2005). Evolutionary trajectories, Internet-mediated expression, and language education. CALICO, 22(3), 371-397. [verified 23 Dec 2010]

https:// www.calico.org/memberBrowse.php?action=article\&id=137

Van Amelsvoort, M. (2009). Podcasting: A view from the trenches. Wireless Ready Symposium EProceedings. [verified 23 Dec 2010] http: / / wirelessready.nucba.ac.jp/ Amelsvoort.pdf

von Konsky, B. R., Ivins, J. \& Gribble, S. J. (2009). Lecture attendance and web based lecture technologies: A comparison of student perceptions and usage patterns. Australasian Journal of Educational Technology, 25(4), 581-595.

http:// www.ascilite.org.au/ajet/ajet25/vonkonsky.html

Dr Karma Pearce, Program Director, Nutrition and Food Sciences

School of Pharmacy and Medical Sciences, University of South Australia

City East Campus, GPO Box 2471, Adelaide SA 5001

Email: karma.pearce@unisa.edu.au Web: http: / / people.unisa.edu.au/Karma.Pearce

Dr Sheila Scutter, School of Health Sciences, University of South Australia

Email: Sheila.Scutter@unisa.edu.au Web: http:/ / people.unisa.edu.au/Sheila.Scutter 